\title{
North Korean Narrative on the Second World War: Why the Change?
}

Fyodor K. Tertitskiy

\author{
Fyodor K. Tertitskiy \\ Kookmin University, Seoul, South Korea \\ Institute for Korean Studies \\ Leading Researcher \\ ORCID: 0000-0002-5414-9500 \\ E-mail: tertitskiyfyodor@gmail.com \\ Address: Kookmin University, Pugak Hall (N2), 1401 (Institute for Korean Studies) \\ 77 Songbuk-ku, Chongnung-ro, Seoul 02707, Republic of Korea
}

This research was supported by the Laboratory Program for Korean Studies through the Ministry of Education of the Republic of Korea and the Korean Studies Promotion Service of the Academy of Korean Studies (AKS-2019-LAB-1250001).

DOI: $10.31278 / 1810-6374-2021-19-4-164-183$

\section{Abstract}

This paper studies North Korea's official narrative on the Second World War. The country is extremely autocratic, meaning that the only allowed vision is the one prescribed by the state. This vision was initially imprinted by the Soviet Union in the late 1940s. However, the official narrative on the Soviet-Japanese War, which led to the establishment of the North Korean state, has been rewritten: today Pyongyang credits Japan's defeat to Kim Il-sung and his "Korean People's Revolutionary Army" - an organization which never existed in reality. This article traces the evolution of the North Korean false narrative and concludes that each of its pages was farther away from historical truth than the previous one.

Keywords: Second World War, historical memory, Korean People's Revolutionary Army, distortion of history, Kim Il-sung, Soviet-Japanese War. 
The Democratic People's Republic of Korea (DPRK) owes its existence to the Second World War. Before World War II, Korea was a Japanese colony, and both the North and South Korean states became independent as a result of Japan's defeat in the war.

The official narrative on the conflict, and on the events that led to the emergence of North Korea in particular, is the most important component of the state ideology. This article studies the evolution of this narrative in the country from the late 1940s to the early 2020s. The research focuses on the description of the Japanese Empire's downfall in 1945 and on how the North Korean official narrative on these events eventually lost touch with reality and became an instrument for the grotesque glorification of the country's founder-Kim Il-sung.

The study shows that the key component of North Korea's state ideology is based on a patently false narrative, which can easily be proven wrong and is sustained only by the country's extremely pervasive censorship. This means that should any liberalization in North Korea occur, the ideological construct would find itself in a highly vulnerable position and since the ruling elite understands this, it is not likely to happen.

The issue of the North Korean vision of WWII may be subdivided into two important parts. The first one is North Korea's perception of the conflict in general, and the second one is Pyongyang's official stance on issues related to Korea itself (above all, the events of the SovietJapanese War of August 1945).

Studies of the North Korean official narrative on world history are, to a certain extent, simplified by the political situation in the country. North Korea is an extreme form of closed society: academic discussion in modern history studies is non-existent as all writers are supposed to unconditionally comply with the state-prescribed dogma. Moreover, unlike other autocracies, North Korea does not permit publishing any books on world history other than textbooks and general encyclopedias. Hence world history plays only a small, or even minute, role in North Korean humanities as compared to national, Korean history.

Thus, the list of publications on the history of the world outside of Korea is extremely narrow. In fact, it is limited to encyclopedias and 
random mention of historical events in the state media and official speeches of the country's leaders.

Today, the research on the North Korean vision of the Second World War is focused almost entirely on Pyongyang's falsification of the events of the Soviet-Japanese War, with the victory primarily attributed to Kim Il-sung since 1967. Of course, the change in the narrative became evident immediately and South Korean encyclopedias of the 1970s duly informed their readers about it (Ch'oe Gwang-sŏk, 1976, p. 679).

Academic explanations of this change can be divided into three groups. The first approach, and assumingly the most popular one, says that the change was part of Kim Il-sung's personality cult inherited from Stalin's USSR. This suggests that the post-1967 rise of the cult was the culmination of its natural development (Sŏ Jae-jin, 2003).

According to the second approach, suggested by Brian Reynolds Myers in his book North Korea's Juche Myth (2015), North Korea is an inherently nationalistic state that covers up its rabid xenophobic views with left-internationalist rhetoric. Accordingly, the changes of 1967 should be seen as primarily and maybe even entirely nationalistic ones, aimed to glorify the Korean ethnos over all others.

The third approach, which appeared in a recently published thesis by Zachary Charles Mulrenin (2020), suggests that the change was largely a response to foreign policy factors, such as the beginning of the Cultural Revolution in China and the subsequent Sino-North Korean split. Mulrenin maintains that Kim Il-sung was inspired by Mao's cult and modeled his own one after him. According to this thesis, Kim viewed the cult as a means of counterbalancing the Chinese influence inside the country.

The explanation offered in this article is built on all the three approaches. The Stalinist historiography and leader-worshipping were undoubtedly the key factors in the formation of the personality cult in North Korea and the official narrative on history. True, North Korea vacillated from Marxist historiography, yet I believe that the new narrative should be viewed as personalistic, not nationalistic because glorifying Kim has always been far more important to Pyongyang than 
extolling the ethnic virtues of the Korean people. Also, I argue here that, although foreign policy factors pointed out by Mulrenin were important, the crucial factor was Kim Il-sung's personal ego: Kim could have reacted to what was going on in China in a myriad of ways, yet he chose extreme self-aggrandisement.

\section{SOVIET ORIGINS OF THE NORTH KOREAN NARRATIVE}

Modern North Korean historiography originated in 1945 with the collapse of the Japanese colonial regime. The Soviet authorities started building humanities in North Korea from scratch with little, if any, regard for the previous tradition. The new North Korean academia was shaped in the style of the Soviet one-as was the country's narrative on the Second World War (General-mayoru <...>, 1945).

As I will show below, while after the 1960s the events of the SovietJapanese War were totally rewritten in North Korea, the Soviet narrative concerning other theaters of WWII and the late-Stalin era remained almost unaltered in North Korea. For example, when speaking about the Molotov-Ribbentrop pact, the secret addendum on the division of Eastern Europe into Soviet and German spheres of influence is not mentioned at all (Ssoryŏn-Toich'willandŭ $\langle\ldots>$, 2001). The North Korean narrative normally omits topics that could be considered problematic in the post-1945 Soviet Union, like the annexation of the Baltic states in 1940, Stalin's failure to predict the German invasion in June 1941, or other events that might portray the Red Army in a negative light.

The narrative on the Holocaust is very similar to the Soviet one even in smaller details (for example, the Auschwitz death camp is referred to by its Polish name Oświęcim) (Osŭbengtchim, 2001). Like Stalin's Soviet Union, North Korea recognizes and condemns Hitler's genocidal policy against the Jews but does not consider it the central crime of the Nazi regime.

North Korean alterations to the general narrative on the Second World War are quite limited. The most significant was perhaps the vilification of Western Allies-the United States and Great Britain. Although the USSR tended to downplay Britain and America's 
contribution to the victory and occasionally blamed them for willing to make a separate peace treaty with Germany, it generally portrayed them as nations fighting for the noble cause of defeating Hitler and his allies.

In North Korea, this was only the case before the Korean War of 1950-1953, when Kim Il-sung personally thanked Britain, the United States, and the Republic of China for the "liberation of Korea" (Kim, 1946, p. 1). After the war, London and Washington's wartime policy was portrayed as "murderous" and "imperialist." Here is a remarkable quote from a North Korean encyclopedia: "In late 1943, American and British imperialists expanded their military activities in the Pacific theater. The American imperialist army of aggression under the command of the infamous murderous commander MacArthur (1880-1964) forcibly occupied several islands in the eastern part of the New Guinea archipelago" (Che2ch'a $<\ldots ., 2000$ ).

Another difference between the Stalinist and North Korean narratives is related to terminology. While in the USSR the war on the Eastern Front was called "the Great Patriotic War," Pyongyang called it the "SovietGerman War" because North Korea has its own Patriotic War-the Korean War of 1950-1953 (Ssoryŏn Toich'willandŭ <...>, 2001).

Meanwhile, the North Korean view of the European theatre of WWII was largely defined by Brezhnev-era Soviet films. A multitude of them were procured by Pyongyang, dubbed to Korean and shown in the country, with the authorities choosing pictures with a simpler patriotic narrative on the Red Army defeating the Hitlerite invaders. Incidentally, this shows that assertions claiming that Pyongyang allegedly sympathized with Hitler (New Focus $<\ldots .>$, 2013), voiced by various sources, are unfounded.

Such consistent Soviet-style portrayal of the WWII events sharply contrasts with the North Korean official view of the Soviet-Japanese War of 1945, as is shown in the section below.

\section{THE MYTH OF THE KOREAN PEOPLE'S REVOLUTIONARY ARMY}

As this section discusses the manipulation of the historical narrative, it would make sense to recall the actual events that took place in North Korea starting from 1945 and Kim Il-sung's role in them. 
In the 1930s, Kim Il-sung, a Manchurian Korean from a family of a teacher, was a middle-to-high ranking commander in the anti-Japanese resistance in Manchukuo. The resistance movement, organized and led by the Communist Party of China, was crushed by the Japanese at the end of the 1930s. To save his life, Kim Il-sung fled to the USSR (Lichnoe delo $<\ldots>$, 1941). Due to extreme manpower shortage in the Red Army's Far Eastern Front, Kim and his comrades were admitted to the ranks of the Red Army in 1942. Kim Il-sung was commissioned as captain and appointed commanding officer of the First Independent Battalion of the 88th Independent Infantry Brigade (Frontovoi prikaz $10 / n, 1945)$. Neither Kim nor his unit participated in the war against Japan, which was launched by the USSR soon after midnight of August 9, 1945 (Chzhou, 1945; Sovetskiye koreitsy <...>, 1945; Spisok lichnogo $\langle\ldots\rangle$, 1945). The war lasted merely a week, as the combined effect of the Soviet attack and nuclear bombings of Japanese cities by the U.S. Air Force made Tokyo surrender on conditions laid down by the Allies.

Yet North Korea attributes the defeat of Japan to Kim Il-sung and the military force he allegedly created and led-the Korean People's Revolutionary Army (KPRA, Chosŏn inmin hyŏngmyŏnggun in Korean). The origins and the evolution of this remarkable falsification are discussed below.

\section{Stage 1 (1945-1952)}

In late 1945, when Kim Il-sung was chosen to lead North Korea, a group of Soviet officers was tasked with crafting a proper biography for the new national leader. The ultimate goal was to pose Kim as a prominent organizer of the anti-Japanese resistance worthy to lead the nascent nation (Smirnov, 1992). Another goal was to cover up Kim's links with the Soviets, specifically the fact that he served in the Red Army (Zhurin, 2011). Thus, the Soviets set two trends regarding Kim: his glorification and presentation as a figure independent of the Soviet Union.

The results were made evident in the first edition of the North Korean Central Yearbook (Chosŏn chungang <...>, 1949), an official 
document that portrayed Kim Il-sung as the leader of the entire resistance movement in Manchukuo and made first mention of the KPRA. At the time, all of the KPRA's alleged operations were limited to Manchuria, and no claims of this "army" fighting in Korea were made.

It is not known who suggested the name "Korean People's Revolutionary Army." Presumably, it could be Kim Il-sung himself: he could coin it after the Northeast People's Revolutionary Army (founded in 1933 by the Communist Party of China) as he served in one of its regiments (Dongbei diqu <...>, 1989, p. 247). Or, alternatively, the KPRA could be coined by someone in the USSR, as a replica of the People's Revolutionary Armies of pre-war Soviet satellite states in Asia-Mongolia, Tuva, and the Far Eastern Republic.

\section{Stage 2 (1952-1967)}

The next stage of the falsification took place in 1952, during the Korean War, when North Korea celebrated Kim Il-sung's 40th birthday. By that time, Pyongyang had secured a certain political independence from Moscow, as Stalin, remembering the legacy of the war with Germany, wanted Kim to act on his own and not to coordinate every decision with his Soviet supervisors (Telegramma $<\ldots>$, 1951).

As a consequence, North Korea started to claim that Kim Il-sung's KPRA participated in the Soviet-Japanese War, and so Japan's defeat in Korea could partially be credited to Kim. This narrative appeared for the first time in 1952 (Kim Il-sŏng changgun <...>, 1952, p. 32) and was duly reiterated in later years (Chosŏn ryŏksa $<\ldots>$, 1955, pp. 115, 117).

Neither de-Stalinization in the Soviet Union nor subsequent events which made Kim Il-sung independent from Moscow's control immediately produced changes in the official narrative. A 1964 book on the Party history still contained only one sentence on the alleged role of the KPRA in the war: “The People's Revolutionary Army, after completing all preparations, participated in the battle to completely destroy Japanese imperialism" (Chosŏn Rodongdang <...>, 1964, pp. 111-112). In August 1966, the country's main newspaper Rodong shinmun still stated: "Our people do not forget that the Soviet people and its great armed forces vanquished the Japanese imperialism and liberated 
our people" (Ch'angjo-wa <...>, 1966, p. 1). It was not until 1967 that North Korea adopted a completely new view of the events of 1945.

\section{Stage 3 (1967-late 1980s)}

The most important change in the North Korean historical narrative occurred in 1967, as from that year on the KPRA was presented as the main force that fought against Japan, while the Soviet Army's role was reduced to an auxiliary one.

The year 1967 saw a significant political shift in North Korea, as the country became much more closed and repressive. The key event that triggered the process was the 15th Plenum of the 4th Central Committee of the Workers' Party of Korea held on May 4, 1967. It introduced the Singular Thought System (yuil sasang ch'egye) that called for total and unconditional loyalty to Kim.

The full text of the decisions introduced at the Plenum remains classified, yet the text was evidently obtained by the South Korean intelligence service, as a book published in 1969 by the chief of Seoul's Institute for Studies of the Communist Bloc contains a summary of the Plenum's decisions. One of them read: "We should obtain a clear understanding of who liberated us from the Japanese imperialism" (Han Jae-dŏk 1969, p. 176). The Plenum had an enormous impact on North Korean society, politics, the personality cult, and the official interpretation of history.

The reasons why this change occurred in 1967 and not earlier or later are still understudied. In his innovative thesis, Zachary Charles Mulrenin (2020) argues that the rise of the cult was impacted by the beginning of the Sino-North Korean split and the purge of a group of top-level officials known as the Kapsan faction. He suggests that these people were linked to China and the extreme amplification of the cult may have been at least partially caused by Kim Il-sung's desire to subvert the Chinese influence, while the glorification of Mao during the Cultural Revolution may have given him some ideas about how to do it.

While this seems to be a reasonable explanation, evidence suggests that the new step was planned well in advance, at least since 1965. In 
that year, the publication of the Pyongyang-controlled Association of North Korean Residents in Japan already hailed Kim Il-sung with the intensity that became commonplace in North Korea after 1967 (Chosŏn minjok-ui <..> 1965, p. 118). This happened before Mao proclaimed the Cultural Revolution and before relations between Beijing and Pyongyang became strained, which shows, at the very least, that China was not the only factor that triggered the change.

Another ideological development was the Juche thought (chuch'e sasang). In 1966, this sobriquet, which reportedly had been coined by Kim Il-sung's deputy Kim Ch'ang-man (Torbenkov, 1960), began to be promoted as North Korea's own ideology. While the Juche thought lacked actual content apart from a few slogans (Myers, 2015, pp. 108-109), it signaled the DPRK's departure from classical Marxism-Leninism and attempt to present itself as the leader of a "third way" in the Communist Bloc, as an alternative to both Moscow and Beijing.

Both these developments were consistent with the new version of the cult. Unlike Marxism-Leninism, which taught that the economy is the sole meaningful driving force of history, North Korea started to claim that history was primarily driven by great individuals-such as Kim Il-sung. The North Korean ideological advance in the Third World (Wŏn, 2016) was mostly promoting Kim Il-sung as such an individual and his new, greatly amplified, cult was an asset in these efforts.

Another consideration was linked to changes in state governance. Dramatic amplification of state control (Kim Chin-gye, 1990, p. 79) was destined to be unpopular and the cult could serve as a method to pacify the people: if Kim Il-sung is just that great, all his policies are bound to be beneficial to the nation in the long run.

To summarize the above, the changes of 1967 were caused by both foreign and internal policy considerations, as well as by Kim Il-sung's growing ego. I would argue that the last one was the most important factor: there were many ways to deal with the challenges the country was facing, but Kim Il-sung chose the most self-flattering one.

The consequences of the new policy became evident soon after it was approved by the Plenum. On August 15, 1967, Rodong shinmun 
credited the victory over Japan to Korean "anti-Japanese partisans" while mentioning the Soviet Army only in passing (T"ujaeng-gwa $<\ldots>$, 1967, p. 1).

Naturally, the dramatic change in the historical narrative was noted by the Soviet Embassy in Pyongyang, which sent multiple reports to Moscow regarding the issue. For example, a 1975 report stated that on the 30th anniversary of North Korean independence, the DPRK press "did not publish any materials at all on the Soviet Union or on the Soviet Army that liberated the country," and that North Korean films "stress that Korea was liberated by the Korean People's Revolutionary Army led by Kim Il-sung” (Kriulin, 1975, pp. 102-113).

The new official narrative faced an unusual problem: by the time it was introduced North Korea had a number of monuments erected in honor of fallen Soviet soldiers. While the main Liberation Monument in Pyongyang remained untouched for diplomatic reasons, the fate of the others was sad.

In 1970, all monuments to Soviet soldiers in Chongjin were reported to have been moved to a faraway district of the city which the diplomats suspected could be off limits to civilians. The diplomats noted that North Koreans had removed the inscription "The Korean people will never forget the Soviet soldiers who fell in the struggle against the Japanese imperialism." According to the report, the mass grave of Soviet soldiers was "in a completely unacceptable state" due to the negligent policy of the local authorities. Finally, in neighboring Rajin, a monument to the Soviet naval landing party during the war was replaced with a monument saying that the landing was conducted by Kim Il-sung-led guerrillas (Kurbatov and Chernikov, 1970, pp. 158-162).

In 1974, the North Korean authorities informed the Soviet Embassy they had moved the mass grave of Soviet soldiers in Wonsan to another location, but that was a post-factum announcement, and the diplomats suspected that the monument had been demolished and a new one had been erected in a less populated area without actually moving the soldiers' remains (Bykov, 1974, pp. 225-227). Another report informed about the demolition of the statue of the Soviet soldier near Pyongyang 
Station, with a North Korean official stating that the monument could be possibly restored (Dudoladov, 1976, pp. 108-109).

Not all people in North Korea accepted the new narrative, and as other reports from the Soviet Embassy said, some North Koreans disagreed and tried to find out how the events of 1945 had really unfolded (Velichko, 1976, pp. 240-246). However, the Soviet Embassy was strictly forbidden from voicing a protest or from doing anything that might upset Pyongyang. It was the time of the Sino-Soviet split, and Moscow's major goal in its North Korea policy was to prevent the DPRK from siding with China. In fact, Nikolai Sudarikov, the Soviet Ambassador to the DPRK in 1967-1974, was explicitly instructed by Prime Minister Kosygin to not antagonize "our flawed friends" (Kapustin, 2020).

The only Soviet reaction to the falsification (Vanin, 2004, pp. 155212) was to continue publishing memoirs about the Soviet-Japanese War (Uspensky, 1964; Vo imya <... , 1965; Na vostochnom <...>, 1969 Osvobozhdenie $\langle\ldots\rangle$, 1976). Although these memoirs still had to comply with Soviet state ideology, they were much closer to the historical truth than the grotesque North Korean narrative. Later, the USSR even declassified some documents and published them as a separate book (Otnosheniya $<\ldots>$, 1981).

Naturally, Pyongyang ignored these Soviet publications, and all new books and media in North Korea reiterated the new version of history. Among the North Korean publications were Kim Il-sung's official biography (Kim Il-sŏng tongji <...>, 1972, pp. 289-291), the Concise History of the Workers' Party of Korea (Chosŏn Rodongdang ryaksa, 1979, pp. 184-188), Complete History of Korea (Chosŏn chŏnsa 1981, 118-133), General Encyclopedia (Chosŏn inmin <...>, 1983, pp. 600-601), and the Synoptic History of Korea (Chosŏn t'ongsa, 1987, pp. 275-279).

As for Moscow, it made no new attempts to stop Pyongyang from further distorting history even after the USSR's conflict with China was over. Presumably, the Soviets understood that this would be a futile endeavor, since by that time the new narrative had become firmly embedded in the North Korean state ideology. 


\section{Stage 4 (1990s-2010s)}

In his later years, Kim Il-sung spent a lot of time reflecting on his past, as is evidenced by the recollections of people who met him at the time (Kim Yŏng-hwan, 2019). This resulted in the publication of Kim Il-sung's official memoirs-an eight-volume book titled With the Century (Kim Il-sŏng tongji $<\ldots .>$, 1998). The narrative presented in the memoirs was even further from the historical truth than the previous North Korean publications.

The book credited the defeat of the Japanese forces in Korea to a "United International Army" composed of the KPRA and its Soviet and Chinese allies, in which Kim Il-sung's troops played the leading role while the Soviet and the Chinese troops provided some limited insignificant assistance.

The book claimed that Kim Il-sung's leading role was well understood by all the parties involved. As an illustration, the memoirs "quoted" Marshal Kirill Meretskov (commanding office of the First Far Eastern Front): "In a war against the Japanese imperialism, Korean comrades are our seniors. The role of Korean comrades in military operations against the Japanese is very important; we have high hopes for you" (Kim Il-sŏng tongji <...>, 1998, p. 450). Moreover, according to the book, before the war, Kim also visited Moscow where Politburo member Andrei Zhdanov informed him that Stalin had told him many things about Korean partisan Kim Il-sung. With the Century claims that Zhdanov was thrilled to hear from Kim that Koreans did not need any aid in reconstructing their country after the war with Japan (p. 451).

The military operations during the war are also described in a way which is even more flattering to Kim. With the Century says that Kim Il-sung instructed the command of the Soviet First Far Eastern Front on the tactics of war, and that the KPRA not only fought in Korea, but also participated in the war against the Kwantung Army in Manchuria. The memoirs name Jinchang, Dongning, Muling and Mudanjiang among the Manchurian cities that were "liberated by the KPRA." Soviet soldiers were apparently overwhelmed with admiration and ecstatically happy to tell Kim that "Korean guerrillas are the greatest." The story of the war ends with the following statement: "The liberation of our 
country was thus achieved by the Korean People's Revolutionary Army, which delivered strong blows against the Japanese imperialists over 15 years and shook their very foundation by mobilizing all the population to the war of resistance. The Soviet operations against Japan ended so quickly only thanks to the long struggle of our army and our people during all those years" (Kim Il-sŏng tongji <...>, 1998, p. 466).

The narrative of With the Century was further substantiated with forged texts. In 1992, North Korea started publishing the Complete Collection of Kim Il-sung's Works, the first volume of which was supposed to contain works that Kim "wrote" before 1945. Arguably, the most interesting forgery in the Vol.1 was Kim Il-sung's "Order on the commencement of the general offensive to liberate the motherland," which allegedly started the KPRA's final offensive (Kim Il-sŏng, 1995, pp. 572-573). Like the rest of the first volume, this order was fabricated. Thus, it should not come as a surprise to the readers that the first volume came out only after Volumes 2-12 were published: it evidently took quite some time for North Korean officials to compose all these fake speeches.

\section{Stage 5 (2010s-present)}

Although Kim Il-sung died in 1994 and Kim Jong-il, his son, heir, and chief architect of his personality cult, died in 2011, the DPRK's myth about the KPRA's "Final Offensive" continues to evolve. Under Kim Jong-un, North Korea started publishing a new, enlarged edition of the Complete Collection of Kim Il-sung's Works. Here, not one, but three volumes are dedicated to the pre-1945 period and, like the original edition, they did not contain a single authentic document.

One may suppose that the purpose of this falsification is to make the DPRK's claim regarding Kim Il-sung's victory over the Japanese more credible-previously it looked as if the KPRA crushed them with little to no preparation. Of course, these "speeches" bear absolutely no resemblance to Kim Il-sung's actual experience in the 1940s. The most vivid example is the speech "given" by Kim on June 22, 1941-the day when Nazi Germany attacked the Soviet Union. According to this narrative, instead of speaking about this extremely important event, 
Kim Il-sung stressed the need to protect the "Paektu Mountain secret camp" (Kim Il-sŏng, 2018c, pp. 394-396). The "camp" itself is another North Korean fabrication-the story tells that it was located on the Korean side of the Paektu Mountain, and that it is the place of Kim Jongil's birth (while in reality Kim Jong-il was born in the Soviet Union).

Another peculiar document is the "speech" Kim Il-sung allegedly gave on June 20, 1941-just before the German invasion began. The speech implies that Kim knew about the impending launch of Operation Barbarossa, as it mentions German troops amassing at the Soviet border-the fact which at that time was known only to a handful of people in the Soviet Union. The subject of his speech is the Soviet-Japanese neutrality pact of 1941; Kim Il-sung says that Korean revolutionaries should not be concerned about it as the Soviet assistance is unnecessary for defeating Japan (Kim Il-sŏng, 2018b, pp. 389-393).

Finally, Volume 3 contains the speech Kim Il-sung allegedly gave on August 15, 1945-the day when Emperor Hirohito announced Japan's surrender (Kim Il-sŏng, 2018a, pp. 535-537). Remarkably, the speech does not give a single reference to the Soviet Army (or, naturally, to any other member of the anti-Japanese coalition). Instead, the victory is credited solely to the Korean resistance. Kim Il-sung is quoted as saying: "During the entire period of the armed struggle, we held fast to the view that we must believe in the strength of our people, mobilize the immeasurable strength of our people and thus fulfil the Korean revolution."

Naturally, the book does not contain any explanation as to why these speeches were neither published nor ever mentioned in the seventy-three years that passed between 1945 and 2018. Like in the previous decades, North Korea has not engaged in any academic discussion; instead, it has doubled down on the false narrative aimed at glorifying the country's first ruler.

The North Korean narrative on the Second World War originated from the Soviet narrative on the immediate post-War period, which was 
implanted into the DPRK by Soviet overseers in the late 1940s. In later years it was altered by the North Korean authorities to fit the changes in the state ideology.

Changes to the general narrative were mostly limited to portraying Britain and the U.S. as villainous states as opposed to "flawed allies"the way these countries were perceived in the Soviet Union.

Changes to the interpretation of the events related to the SovietJapanese War were overarching. The myth of Kim Il-sung as the commander of the Korean People's Revolutionary Army, relatively modest at first, evolved through several stages and ripened in 1967. Since then, the North Korean narrative regarding the events of 1945 and the DPRK's legitimacy has been amplified by flagrant lies and alleged sources invented decades after the events.

Such historical falsification became possible due to an extremely closed nature of the North Korean state. Understandably, even a small degree of academic freedom would have made the state mythology vulnerable to criticism, and any political liberalization would have posed a great threat to the stability of the North Korean statehood.

\section{References}

Babikov, M., 1969. Na vostochnom beregu [On the Eastern Seashore]. Moscow: Sovetskaya Rossiya.

Bykov, V., 1974. O perenose pamyatnika sovetskim voinam v Vonsane [On the Move of the Monument to Soviet Soldiers in Wonsan]. Russian State Archive for Contemporary History, 9 September Collection 5, Folder 67, Item 718, pp. 225-227.

Ch'angjo-wa $\langle\ldots\rangle$, 1966. Ch'angjo-wa pŏnyŏng-ŭi sŭmul han hae [Twenty-One Years of Creation and Prosperity]. Rodong sinmun, 15 August, p. 1.

Ch'oe Gwang-sŏk., 1976. Pukhan yongŏ taebaekkwa [Grand Encyclopaedia of North Korean Terminology]. Seoul: Kungmin pangch'ŏp yŏn'guso [Research Center for Civil Counterintelligence].

Che2ch'a $\langle\ldots\rangle, 2000$. Che2ch'a segye taejŏn [The Second World War]. In: Chosŏn taepaekkwa sajŏn [Grand Encyclopaedia of Korea], Vol. 20. Pyongyang: Paekkwa sajŏn ch'ulp'ansa, pp. 371-377. 
Chosŏn chŏnsa, 1981. Chosŏn chŏnsa [Complete History of Korea], Vol.22. Pyongyang: Kwahak, paekkwa sajŏn chonghap Ch'ulp'ansa.

Chosŏn chungang <...>, 1949. Chosŏn chungang nyŏn'gam 1949 [Korean Central Yearbook 1949]. Pyongyang: Chosŏn chungang t'ongsinsa.

Chosŏn inmin $\langle\ldots\rangle, 1983$. Chosŏn inmin hyŏngmyŏnggun-ŭi ch'oehu konggyŏk chakchŏn [The Final Offensive of the Korean People's Revolutionary Army]. In: Paekkwa chŏnsŏ [General Encyclopaedia], Vol. 4. Pyongyang: Kwahak, paekkwa sajŏn Ch'ulp'ansa, pp. 600-601.

Chosŏn minjok-ui $\langle\ldots>, 1965$. Chosŏn minjok-ui widaehan ryŏngdoja [The Great Guide of the Korean Nation]. Tokyo: Chosŏn sinbo sa.

Chosŏn Rodongdang $\langle\ldots\rangle$, 1964. Chosŏn Rodongdang ryŏksa kyojae [Teaching Materials of the History of the Workers' Party of Korea]. Pyongyang: Chosŏn Rodongdang Ch'ulp'ansa.

Chosŏn Rodongdang ryaksa, 1979. Chosŏn Rodongdang ryaksa [Concise History of the Workers' Party of Korea]. Pyongyang: Chosŏn Rodongdang Ch'ulp'ansa. Chosŏn ryŏksa $<\ldots>$, 1955. Chosŏn ryŏksa. Kogŭp chung [History of Korea. High School]. Pyongyang: Kyoyuk tosŏ Ch'ulp'ansa.

Chosŏn t'ongsa, 1987. Chosŏn t'ongsa [A Synoptic History of Korea]. Pyongyang: Sahoe kwahak Ch'ulp'ansa.

Chzhou Baochzhun [Zhou Baozhong], 1945. Pis'mo komandira 88-i otdelnoi brigady glavnokomanduyushchemu Sovetskimi voiskami na Dalnem Vostoke s predlozheniyami po ispolzovaniyu brigady [A Letter of the Commanding Officer of the 88th Independent Infantry Brigade to the Commander-in-Chief of the Soviet Forces in the Far East with Suggestions on Using the Brigade]. Central Archive of the Russian Ministry of Defense, Collection 66, Inventory 3191, Folder 2, pp. 14-15. Quoted from V. N. Vartanov and A. N. Pochtaryov, 1997. "Stalinsky spetznaz": 88-ya otdelnaya strelkovaya brigada ["Stalin's Special Forces": 88th Independent Infantry Brigade]. Novy chasovoi, 5, pp. 178-179.

Dongbei diqu $\langle\ldots\rangle$, 1989. Dongbei diqu geming lishi wenjian huiji [Document Collection on the Revolutionary History of the Northeast]. Vol. 30, Harbin: Heilongjiangsheng chubanzongshe.

Dudoladov, Yu., 1976. Zapis' besedy s otvetstvennym referentom I Departamenta MID KNDR Li San Synom [Record of Conversation with Lee San-sŭng, Senior Instructor of the First Department of the Ministry of Foreign Affairs of the DPRK, 30 August]. Russian State Archive for Contemporary History, Collection 5, Folder 69, Item 2427, pp. 108-109. 
Frontovoi prikaz 10/n, 1945. Frontovoi prikaz 10/n [Front Order 10/n, 29 August 1945]. Central Archive of the Russian Ministry of Defense, Collection 33, Inventory 687572, Item 2317.

General-mayoru <...>, 1945. General-mayoru Romanenko. O sostoyanii i prodelannoi rabote $\mathrm{v}$ oblasti narodnogo prosvescheniya v Severnoi Koree [To Major-general Romanenko. On the current state and the work done in education in North Korea. 30 November 1945]. Central Archive of the Russian Ministry of Defense of Russia, Collection of the Directorate of the Soviet Civil Administration, Folder 433847, Item 1, pp. 212-214.

Han Jae-dŏk, 1969. Kim-il-sŏng-gwa Pukkoe-ŭi shilsang [Kim Il-sung and the Current State of the North Korean Puppet Regime]. Seoul: Kongsan'gwŏn munje yŏn'guso.

Kapustin, D., 2020. Author's conversation with Dmitry Kapustin, a former Soviet diplomat in Pyongyang in the late 1960s.

Kim Yŏng-hwan, 2019. Author's conversation with Kim Yŏng-hwan, former proNorth Korean activist who met Kim Il-sung in 1991.

Kim Il-sŏng changgun $\langle\ldots>$, 1952. Kim Il-sŏng changgun-ŭi ryakchŏn [A Short Biography of Commander Kim Il-sung]. Pyongyang: Chosŏn Rodongdang Chungang Wiwŏnhoe Sŏnjŏn Sŏndongbu.

Kim Il-sŏng tongji $\langle\ldots\rangle$, 1972. Kim Il-sŏng tongji ryakchŏn [A Concise Biography of Comrade Kim Il-sung]. Pyongyang: Chosŏn Rodongdang Ch'ulp'ansa.

Kim Il-sŏng tongji $\langle\ldots>$, 1998. Kim Il-sŏng tongji hoegorok Segiwa tŏburŏ (kyesŭngbon) [Comrade Kim Il-sung's Memoirs "With the Century" (PostMortem Publication)]. Vol. 8, Pyongyang: Chosŏn Rodongdang Ch'ulp'ansa.

Kim Chin-gye, 1990. Choguk - ŏnŭ Puk Chosŏn inmin-ŭi sugi. [The Motherland: Notes of One of the North Korean People]. Vol. 2. Seoul: Hyŏnjang munhaksa.

Kim Il-sŏng, 1946. Sinnyŏn-ul majihamyŏnsŏ uri inmin-ege turim [A Message for Our People on the Occasion of the New Year]. Chŏngno, 1 January, p. 1.

Kim Il-sŏng, 1995. Myŏngnyŏng. Choguk haebang-ŭl wihan ch'ongkonggyŏkchŏn-ŭl kaesiha-l-te taeha-yŏ [Order. On the Commencement of the General Offensive to Liberate the Motherland]. In: Kim Il-sŏng chŏnjip [Complete Works of Kim Il-sung]. Pyongyang: Chosŏn Rodongdang Ch'ulp'ansa, 1995, pp. 572-573. 
Kim Il-sŏng, 2018a. Choguk haebang kyŏngch'uk moim-esŏ han yŏnsŏl [Speech at the Meeting to Celebrate the Liberation of the Motherland]. In: Kim Il-sŏng chŏnjip (chŭngbop'an) [Complete Works of Kim Il-sung (Expanded Edition)], Vol. 3. Pyongyang: Chosŏn Rodongdang Ch'ulp'ansa, pp. 535-537.

Kim Il-sŏng, 2018b. Uri-ŭi him-ŭro Chosŏn hyŏngmyŏng-ŭl wansu-hayŏya handa [The Korean Revolution Must Be Completed with Our Own Strength]. In: Kim Il-sŏng chŏnjip (chŭngbop'an) [Complete Works of Kim Il-sung (Expanded Edition)], Vol. 3. Pyongyang: Chosŏn Rodongdang Ch'ulp'ansa, pp. 389-393.

Kim Il-sŏng, 2018c. Paektusan miryŏng-ŭl t'ŭnt'ŭnhi powihayŏya handa [We Must Thoroughly Protect the Paektu Mountain Secret Camp]. In: Kim Il-sŏng chŏnjip (chŭngbop'an) [Complete Works of Kim Il-sung (Expanded Edition)], Vol. 3. Pyongyang: Chosŏn Rodongdang Ch'ulp'ansa, pp. 394-396.

Kriulin, G., 1975. O meropriyatiyakh v KNDR v svyazi s 30-letiyem osvobozhdeniya Korei Sovetskoi Armiei [On the Events Held in the DPRK to Celebrate the 30th Anniversary of the Liberation of Korea by the Soviet Army. 18 August 1975]. Russian State Archive for Contemporary History, Collection 5, Folder 68, Item 1866, pp. 102-113.

Kurbatov, M. and Chernikov, V., 1970. Informatsiya o meropriyatiyakh provedennyh koreyskimi tovarihschami $\mathrm{v}$ svyazi s otkrytiyem perenesyonnykh pamyatnikov sovetskim voinam $\mathrm{v}$ gorode Chondine [Information Letter on Measures Taken by Korean Comrades with regard of the Opening of Memorials to Soviet Soldiers in the City of Chongjin. 2 September 1970]. Russian State Archive for Contemporary History, Collection 5, Folder 62, Item 455, pp. 158-162.

Lichnoe delo <...>, 1941. Lichnoe delo Tszin Zhi-chena [Jin Richeng's Personal File]. Russian State Archive of Socio-Political History, Collection 495, Inventory 238, File $60 .{ }^{1}$

Mulrenin, Zachary Charles, 2020. "They Wanted to Cut Off My Head": The Impact of the People's Republic of China on the Personality Cult of Kim Il Sung, 1956-1969. MA Thesis, University of Virginia.

Myers, B., 2015. North Korea's Juche Myth. Pusan: Shtele Press.

New Focus $\langle\ldots>$, 2013. North Korea looks towards Hitler and the Third Reich. New Focus International, 17 June 2013 [online]. Available at: <web.archive.org/ web/20170714215034/http://newfocusintl.com/north-korea-hitler-third-reich/> [Accessed 2 April 2021].

\footnotetext{
1 "Jin Richeng" is an alternate spelling of "Kim Il-sung" which originated from the Chinese reading of characters composing Kim's name.
} 
Otnosheniya $\langle\ldots>$, 1981. Otnosheniya Sovetskogo Soyuza s narodnoi Koreei. 1945-1980. Dokumenty i materialy. [Relations of the Soviet Union and the People's Korea. 1945-1980. Documents and materials]. Moscow: Nauka.

Osŭbengtchim, 2001. Osŭbengtchim [Oświęcim], in Chosŏn taepaekkwa sajŏn [Grand Encyclopaedia of Korea], vol. 27. Pyongyang: Paekkwa sajŏn ch'ulp'ansa, p. 467.

Osvobozhdenie $\langle\ldots>$, 1976. Osvobozhdeniye Korei. Vospominaniya i stat'i [Liberation of Korea, Reminiscences and articles]. Moscow: Nauka.

Smirnov, A., 1992. Kim Ir Sen-podkidysh. Kak Sovetskaya Armiya vnedrila v Severnuyu Koreyu prezidenta Kim Ir Sena i yego pravitel'stvo [Kim Il-sung the Foundling. How the Soviet Army implanted President Kim Il-sung and his Government to North Korea]. Sovershenno Sekretno, pp. 10-11.

Sŏ Jae-jin., 2003. Pukhan-ŭi kaein sungbae mit chŏngch'i sahoehwa-ŭi hyogwae taehan p'yŏngga yŏngu [Evaluation of effects of personality cult and politicisation of the society on North Korea]. Seoul: T'ongil yŏn'guwŏn [Korean Institute for National Unification] [online]. Available at: <lib.uniedu.go.kr/ libeka/elec/0000598220.pdf> [Accessed 2 April 2021].

Sovetskiye koreitsy $\langle\ldots\rangle, 1945$. Sovetskiye koreitsy, nakhodivschiesya v sostave 88 -i osbr (s. Vyatskoye), prednaznachennye dlya raboty v Koree [Soviet Koreans Serving in the 88th Independent Infantry Brigade (Vyatskoye village) and Assigned to Work in Korea]. 31 August 1945. Central Archive of the Russian Ministry of Defense, Collection 2, Inventory 19121, Folder 2, p. 15.

Spisok lichnogo $\langle\ldots\rangle$, 1945. Spisok lichnogo sostava 1-go batal'ona 88-y otd. str. Brigady 2-go Dal'nevostochnogo fronta, prednaznachennogo dlya raboty $\mathrm{v}$ Koree [A list of personnel of the 88th Independent Infantry Brigade which is to be dispatched to work in Korea]. Central Archive of the Russian Ministry of Defense, collection 3, inventory 19121, folder 2, pp. 14-15.

Ssoryŏn Toich'willandŭ $\langle\ldots\rangle, 2001$. Ssoryŏn Toich'willandŭ chŏnjaeng [SovietGerman war] in Chosŏn taepaekkwa sajŏn [Grand Encyclopaedia of Korea], vol. 26. Pyongyang: Paekkwa sajŏn ch'ulp'ansa, pp. 173-174.

Ssoryŏn-Toich'willandŭ $\langle\ldots\rangle, 2001$. Ssoryŏn-Toich'willandŭ pulgach'im choyak [Soviet-German non-aggression pact] in Chosŏn taepaekkwa sajŏn [Grand Encyclopaedia of Korea], vol. 26. Pyongyang: Paekkwa sajŏn ch'ulp'ansa, p. 173.

Telegramma $\langle\ldots>$, 1951. Telegramma Predsedatelya Soveta Ministrov SSSR Glavnomy voennomu sovetniku Koreiskoi Narodnoi armii s ukazaniyem razobrat'sya $\mathrm{v}$ suti poslannyh emu rannee predlozhenii o povyshenii 
boesposobnosti KNA [Telegram from the Chairman of the Council of Ministers of the USSR to the Chief Military Advisor to the Korean People's Army with instructions to sort out the essence of the proposals sent earlier to him to increase the combat effectiveness of the KPA]. 3 February 1951. Archive of the President of the Russian Federation, collection 45, folder 1, item 348, p. 20.

Torbenkov, N. E., 1960. Zapis' besedy s sovetnikom MID MNDR Pak Dok Hvanom. [Record of conversation with Pak Dok-hwan, councillor of the DPRK's Ministry of Foreign Affairs]. 1 June. Archive of the Foreign Policy of the Russian Federation, collection 0102, folder 16, item 6.

T'ujaeng-gwa $\langle\ldots>$, 1967. T'ujaeng-gwa sŭngni-ŭi sŭmul tu hae [Twenty-Two Years of Struggle and Victories]. Rodong sinmun, 15 August 1967, p.1.

Uspenskiy, V., 1964. Glazami matrosa [Through a Seaman's Eyes]. Moscow: Voyenizdat.

Vanin, Yu., 2004. Izuchenie istorii Korei [Historical studies of Korea] in Koreevedeniye $v$ Rossii: istoriya i sovremennost' [Korean studies in Russia: history and current state]. Moscow: Pervoye Marta, pp. 155-212.

Velichko, E., 1976. O nekotoryh politicheskih nastroeniyah trudyastchihsya KNDR [On tendencies in some political views of the labouring people of the DPRK], 6 December 1976. Russian State Archive for Contemporary History, collection 5, inventory 64, folder 2422, pp. 240-246.

Vo imya $\langle\ldots\rangle, 1965$. Vo imya druzhby s narodom Koreii. Vospominaniya i stat'i. [In the Name of Amity with the Korean People. Reminiscences and articles]. Moscow: Nauka.

Wŏn Chi-u, 2016. Pukhan-ŭi tae Chungdong mit Ap'ürik'a oegyo: oegyo chŏngch'aek kyŏlchŏng yoin-ŭl chungshim-ŭro [North Korea's foreign policy towards the Middle East and Africa: Factors in decision making], MA thesis, Korea University.

Zhurin, A., 2011. Sdelan v SSSR [Made in the USSR]. Sovershenno sekretno No.9/268 [online]. Available at: <web.archive.org/web/20150628072203/http:// www.sovsekretno.ru/articles/id/2889/> [Accessed 2 April 2021]. 